\title{
RESEARCH ON DECREASE OF OUTSIDE AIR HEAT PUMP PASSIVE EVAPORATORS ICE-COVER
}

\author{
Andrievs Ilsters, Imants Ziemelis \\ Latvia University of Agriculture, Research Institute of Agricultural Machinery \\ 1 Instituta St, Ulbroka, Riga region, Latvia \\ E-mail: Ilsters_uzc@apollo.lv; Imants.Ziemelis@1lu.lv
}

\begin{abstract}
Two years (2009-2010) experience of the experimental use of alternative energy sources in technological processes of agriculture is analyzed. Water was heated by an outside air heat pump with passive evaporators, and used for new born piglets resting place floor heating. Experimental data were obtained by the reckoning consumption of electric energy for the operation of the heat pump's compressor and electric heater, and by a heat meter registering the consumed heat energy.

The obtained data show that the outside air heat pump with passive evaporators is working successfully during summer months, when the coefficient of performance (COP) of the heat pump exceeds 3.5. When the outside temperature decreases under $+10^{\circ} \mathrm{C}$, the heat pump evaporators become covered with hoarfrost and ice. The value of the COP and produced amount of heat energy reduce, and the electric heater often switches on. During the experimental research one of the heat pump evaporators was supplied with a ventilator, air flow from which was washing the surface of the evaporator's plates. So the satisfactory operation of the heat pump was provided till December 10, 2009 and November 25, 2010.
\end{abstract}

Keywords: coefficient of performance, heat pump, ice coverage.

\section{Introduction}

In order to widen the use of renewable energy sources in Latvia, detailed investigation, advance and support on technological investigation issues is needed. Particularly it concerns the use of heat pumps in the climatic conditions of Latvia. It is important to find out its place in the energy supply system for today and future [1]. Producers and disseminators of heat pumps are organizing impressive reclamation campaigns with recommendations on the use of heat pumps for living house heating, particularly when heated floors are introduced. The heat energy can be taken from the ground, water or air. An attention deserves the latest projects, realised in Latvia, about the use of heat pumps, where the heat is taken from the sea (Salacgriva) and the lake (Katvari).

The efficiency of an outside air heat pump essentially depends on the air temperature. The heat transformation ability is determined by coherence [2]:

$$
C O P=\frac{T_{H}}{T_{H}-T_{L}},
$$

where $C O P$ - coefficient of performance of the heat pump;

$T_{H}$ - highest (necessary for consumer) temperature, ${ }^{\circ} \mathrm{C}$;

$T_{L}$ - lowest (heat source) temperature, ${ }^{\circ} \mathrm{C}$.

The heat pump's coefficient of performance (COP) is smaller at lower value of the outside air temperature. It is exactly when the need for heat is the highest. Therefore in case when the heat pump is not able to produce the necessary amount of heat energy, additional heat producing advices are envisaged.

Conditions, different from living houses are in warmed domestic animal cattle-sheds, where intensive ventilation system is working. There polluted inside air is delivered out from the premises and the fresh and clean air is brought in. With the polluted air considerable amount of heat is lost. At the same time in order to maintain the necessary temperature inside the sucking and weaned piglet premises, all the year round electric heaters or heating boilers are used. The fossil energy consumption rises and the environment becomes spoiled. 
By setting up pigsties with heat pumps of an appropriate power, during the period of hot weather it is possible to provide for heating piglets resting place floor without using additional heaters. Working out the solution of recovering the heat from brought out by ventilation system polluted but warm air, it could be possible to provide for heat pump operation at lower outside temperature, that is, during the heating period also. As a result the consumption of fossil energy would be diminished.

The objective of the research is to ascertain the suitability of the use of outside air heat pump for piglets resting place floor heating, putting particular attention to the possibility of providing for high heat transmission coefficient (COP) of the heat pump during could and frosty weather conditions.

\section{Materials and methods}

For the experimental investigation an outside air heat pump with passive evaporators has been used. The compressor of the heat pump is driven by the electric motor of $5 \mathrm{~kW}$ power. The power of produced heat energy is up to $17 \mathrm{~kW}$. The power of additional electric heater is 12 $\mathrm{kW}$. The heat pump was installed at one of sows farrowing sections with two compartments, where 96 farrowing places are set. The passive evaporators are places outside the piggery, but compressor and other equipment - inside the piggery. The hot water, heated by the heat pump up to $45-50^{\circ} \mathrm{C}$ by means of a circulation pump through the pipe system to each of farrowing pens with heating floor panels has been delivered. The heat load of each of heating panels is $180 \mathrm{~W}$.

During the experimental investigation the panels' surface temperature within the limits of 35$36^{\circ} \mathrm{C}$ has been kept. The circulation pump operation regime after the back flow water temperature has been controlled, keeping it within the limits of $36-38^{\circ} \mathrm{C}$.

Data about the produced amount of heat energy and consumed electric energy for heat pump compressor's and electric heater operation have been registered. The efficiency of the heat pump operation during certain periods has been estimated, establishing the COP and energy transfer coefficients using coherencies [1]

$$
\begin{aligned}
& C O P=\frac{Q}{P_{c}} \\
& K=\frac{Q}{P}
\end{aligned}
$$

where $K$ - energy transfer coefficient;

$Q$ - produced amount of heat energy, $\mathrm{kWh}$;

$P_{c}$ - electric energy consumed for compressor's operation, kWh;

$P$ - total consumption of electric energy, $\mathrm{kWh}$.

For the registration of the consumed electric energy two 3-faze electric meters has been used, with the accuracy $0.01 \mathrm{kWh}$. One of them registered the electric energy consumed for the operation of the heat pump's compressor, and another one, additionally consumed electric energy by the electric heater. Produced amount of heat by the use of heat meter SONOMETER $^{\mathrm{TM}} 1000$ (accuracy $1 \mathrm{kWh}$ ) has been measured. The heat meter allows in every time moment to read of the efficiency of the hot water flow, the temperature of the heated floor inflow and outflow water, and the heat energy power as well. Average daily and monthly outside air temperatures during the experiment from the data base of the State Meteorological Service has been taken [3].

In order to carry out the experimental investigation on the possibility of the decrease of hoarfrost and ice coverage of the heat pump evaporators, one of them was provided for a ventilator (efficiency $1.2-1.4 \mathrm{~m}^{3} / \mathrm{s}$ ), which air flow on the evaporators' plates has been directed. 


\section{Results and Discussion}

The heat energy, produced by the heat pump, was used for piglets resting place floor panels' heating. From the data given in Table 1, about the exploitation parameters of the heat pump obtained in 2009 and 2010, firstly, direct relationship between the outside air temperature and COP of the heat pump is seen. Secondly, during the warm months of the summer - July and August, the consumption of heat is essentially smaller. The heat pump all the necessary amount of heat is able to produce with breaks at $\mathrm{COP}>3.5$. At the temperature under $10^{\circ} \mathrm{C}$ and down to the positive temperature above $0^{\circ} \mathrm{C}$, the character of the operation of the heat pump changed. Particularly it is seen from the data about October and November, when the average temperature was $5-6^{\circ} \mathrm{C}$ and the evaporators' plates started to be covered with hoarfrost and ice. The demand of heat for keeping the floor temperature in the necessary level increases also. The heat pump's compressor in the majority was working continuously. Not always the ice thawed from the heat evaporator plates, when the temperature in the middle of a day increased. As a result the COP of the heat pump felt down to 2.8-2.6. The common heat transfer coefficient reduced to 2.3-2.6. In certain time periods, particularly in nights, the electric heater switched on. The hoarfrost of radial placed evaporators' plates increased so intensively that the evaporators entirely were covered by the ice and visually took a cylindrical shape.

Table 1.

Exploitation indexes of the heat pump with passive evaporators in 2009 and 2010

\begin{tabular}{|c|c|c|c|c|c|c|c|c|}
\hline \multirow{3}{*}{ Months } & \multirow{2}{*}{\multicolumn{2}{|c|}{$\begin{array}{l}\text { Average outside } \\
\text { air temperature, } \\
{ }^{0} \mathrm{C}\end{array}$}} & \multirow{2}{*}{\multicolumn{2}{|c|}{$\begin{array}{c}\text { Specific heat } \\
\text { consumption, } \\
\text { kWh/h }\end{array}$}} & \multicolumn{4}{|c|}{ Compressors' common } \\
\hline & & & & & \multicolumn{2}{|c|}{ COP } & \multicolumn{2}{|c|}{$\mathbf{K}$} \\
\hline & 2009 & 2010 & 2009 & 2010 & 2009 & 2010 & 2009 & 2010 \\
\hline May & - & 11.0 & - & 8.46 & - & 3.00 & - & 2.95 \\
\hline June & 14.0 & 14.9 & 10.01 & 9.98 & 3.06 & 3.23 & 3.06 & 3.20 \\
\hline July & 17.4 & 21.5 & 5.27 & 5.45 & 3.32 & 3.67 & 3.32 & 3.67 \\
\hline August & 16.0 & 18.8 & 9.16 & 7.48 & 3.25 & 3.55 & 3.25 & 3.35 \\
\hline September & 13.6 & 11.5 & 8.13 & 9.51 & 3.24 & 2.90 & 3.24 & 2.90 \\
\hline Oktober & 5.0 & 4.9 & 9.75 & 12.87 & 2.63 & 2.78 & 2.34 & 2.49 \\
\hline November & 4.8 & 6.1 & 10.13 & 11.29 & 2.58 & 2.85 & 2.01 & 2.62 \\
\hline December & 3.5 & - & 9.78 & - & 2.33 & - & 2.09 & - \\
\hline Average & 10.6 & 12.7 & 8.89 & 9.29 & 2.91 & 3.14 & 2.76 & 3.02 \\
\hline
\end{tabular}

Technical solutions for the diminishing of the hoarfrost and taking off the ice from the evaporators' plates have been looked for. They are based on the direction of the warm air flow on the evaporators' plates. The first investigations in the exploitation season of 2009 have been carried out. Around one of the evaporator blocs an isolation square box, where by means of a ventilator from one side the air from outside or the pigsty ante-room has been blown in. The average increase in heat energy power by $0.8-3.2 \mathrm{~kW}$ has been obtained and the thaw of hoarfrost has been furthered [4]. During the further work this principle has been changed. The additional air flow was directed parallel to the evaporator's plates. It was completed placing the ventilator above the evaporator's block and by means of a special cone moving the air flow to the evaporator's plates (Fig.1). In order to intensify the process, the possibility to cover the evaporator's block from both outside and inside with special screens has been envisage. 


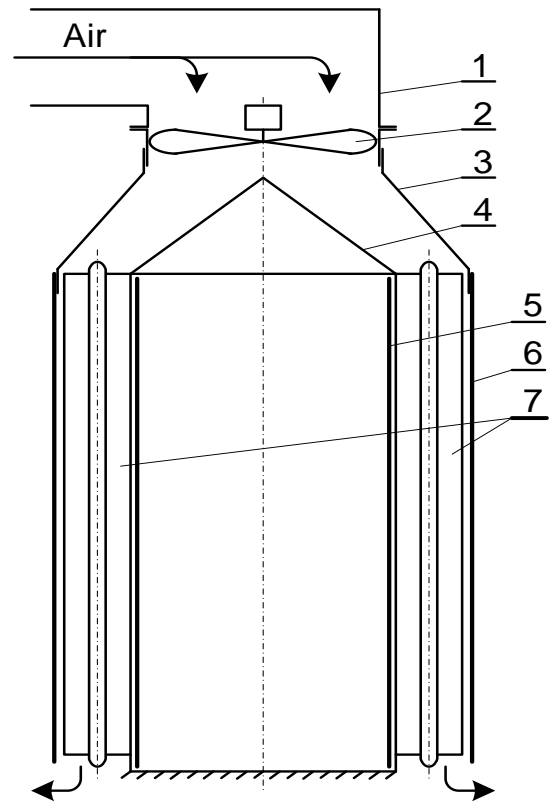

Fig. 1. Scheme of screens for air flow movement parallel to evaporator plates:

1 - air canal; 2 - ventilator; 3 - cover; 4 - cone; 5 inside screen (movable); 6 - outside screen (movable); 7 - evaporator's block

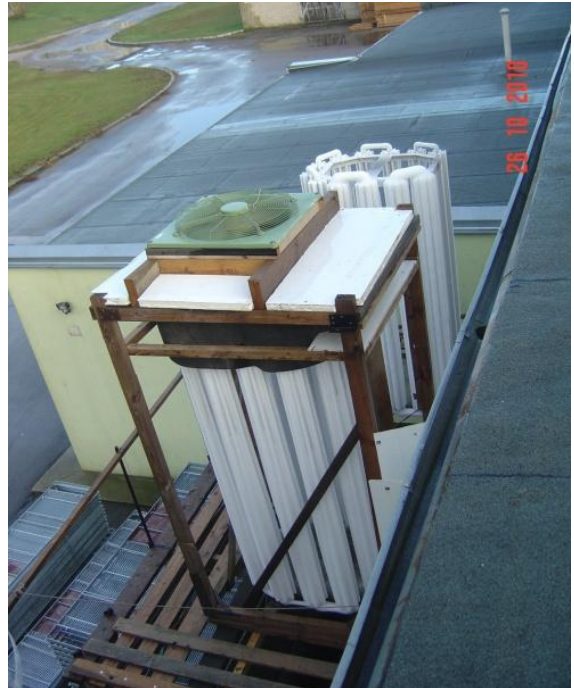

\section{Fig.2. Ventilator above the heat pump evaporator}

Experimental results on the promotion of the ice thaw from the evaporator's plates by short time moving the air flow to evaporator's plates, and by long time moving the air flow to evaporator's plates in order to improve the heat pump operation. Results in Table 2 when the air flow is directed to the evaporator's plates, corresponds to regime " 1 ". Period of time from September 1 to September 9 the heat pump was working in constant regime " 0 ". Consumption of heat on the average was $9.5 \mathrm{kWh} / \mathrm{h}$ at the COP $=2.80$. In the morning of September 9 at the outside air temperature $9-10^{\circ} \mathrm{C}$ the evaporator's plates were covered by the hoarfrost, and the heat pump was working continuously with heat power $9.6-10.4 \mathrm{~kW}$, at the $\mathrm{COP}=$ 2.58. In the next morning (September 10) at similar weather conditions switching on the ventilator and starting to direct the air flow to the evaporators plates, during several minutes the heat power from $10.4 \mathrm{~kW}$ increased to $12.5 \mathrm{~kW}$. The compressor switched off and the thaw of the evaporator's plates started. When the compressor switched on next time, the heat power rose up to $13.8 \mathrm{~kW}$. After some time when the ventilator was switched off, the heat power diminished a little, because the evaporator plates already were free from hoarfrost. Similar examination was repeated several times. The main gain from the additional switching on and off of the ventilator is to contribute to the thawing of the evaporators' plates, which after that improves the parameters of the neat pump for longer time.

Greater effect has been reached at additional operation of the ventilator in the first week of October (2009), when the temperature lowered under $5-8^{\circ} \mathrm{C}$. On October 9 the ventilator has been operating all the day round (Fig.2). At the heat consumption $12.8 \mathrm{kWh} / \mathrm{h}$ the reached heat power was $15.2 \mathrm{~kW}$ at the $\mathrm{COP}=3.08$, including the energy consumed for the ventilator's operation $\mathrm{K}=2.64$ ).

The two last rows in Table 2 reflect the average results of the long term operation of the heat pump at outside air temperature $5-6^{\circ} \mathrm{C}$. From October 5 to 10 when the ventilator was out of operation, the compressor's COP on the average was 2.53. As for some time the electric heater has been operating, the common energy transfer coefficient was $\mathrm{K}=2.26$. 
From October 10 till November 4 the ventilator was operating constantly. Therefore the hoarfrost essentially reduced, the air flow around the evaporator's plates was more intensive and the electric heater did not switch on. In result at the average heat consumption 12.2 $\mathrm{kWh} / \mathrm{h}$ the compressor's COP increased up to 2.89 , and including the ventilator's consumed power, the common coefficient $\mathrm{K}$ was 2.58 .

Table 2.

Increase in heat pump operation results in September-October, 2010 coursed by outside air flow

\begin{tabular}{|c|c|c|c|c|c|c|c|c|c|}
\hline \multirow[t]{2}{*}{ Date } & \multirow[t]{2}{*}{$\mathbf{R}$} & \multirow{2}{*}{$\underset{h}{\text { Time, }}$} & \multicolumn{3}{|c|}{$\begin{array}{c}\text { Outside air } \\
\text { temperature, }{ }^{\circ} \mathrm{C}\end{array}$} & \multirow{2}{*}{$\begin{array}{c}\mathbf{Q}, \\
\mathbf{k W h} / \\
\mathbf{h}\end{array}$} & \multirow{2}{*}{$\begin{array}{l}\mathbf{N}, \\
\mathbf{k W}\end{array}$} & \multirow[t]{2}{*}{ COP } & \multirow[t]{2}{*}{$\mathbf{K}$} \\
\hline & & & average & $\min$ & $\max$ & & & & \\
\hline Sept. $1-9$ & 0 & 216 & 12 & 9 & 18 & 9.5 & & 2.80 & 2.80 \\
\hline Sept. 9 & 0 & 2 & 9 & & & 10.0 & $9.6-10.4$ & 2.58 & 2.58 \\
\hline \multirow{2}{*}{ Sept. 10} & 1 & 0.35 & 10 & 10 & 10 & 10.0 & $12.5-13.8$ & & \\
\hline & 0 & 6 & 13 & 10 & 15 & 10.0 & $13.8-12.3$ & 3.16 & 3.13 \\
\hline Sept. $10-13$ & 0 & 65.5 & 15 & 13 & 18 & 9.98 & $12.3-10.2$ & 3.14 & 3.14 \\
\hline Sept. 3 & 1 & 3.5 & 17 & 14 & 19 & 8.00 & 13.2 & 3.04 & 2.97 \\
\hline \multirow{3}{*}{ Oct. 6} & 0 & 2.4 & 4 & 4 & 6 & 11.25 & 11.3 & 2.49 & 2.49 \\
\hline & 1 & 0.15 & 6 & 6 & 6 & & $11.3-14.2$ & & \\
\hline & 0 & 0.5 & 6 & 6 & 6 & & $14.2-11.4$ & & \\
\hline \multirow{2}{*}{ Oct. 7} & 0 & 7.7 & 5 & 3 & 8 & 12.76 & 14.2 & 2.50 & 1.94 \\
\hline & 1 & 0.7 & 8 & 8 & 8 & 12.86 & & 3.10 & 2.77 \\
\hline Oct. $7-8$ & 0 & 21.2 & 4 & 2 & 8 & 10.87 & 10.5 & 2.51 & 2.51 \\
\hline Oct. $8-9$ & 0 & 18.4 & 5 & 3 & 9 & 11.45 & 12.6 & 2.11 & 1.77 \\
\hline Oct. 9 & 1 & 7 & 7 & 3 & 9 & 12.8 & 15.2 & 3.08 & 2.64 \\
\hline Oct. $5-10$ & 0 & 110 & 6 & 2 & 11 & 11.99 & & 2.53 & 2.26 \\
\hline $\begin{array}{l}\text { Oct. } 10- \\
\text { Nov. } 4\end{array}$ & 1 & 599 & 5.3 & 2 & 8 & 12.19 & $10-14$ & 2.89 & 2.58 \\
\hline
\end{tabular}

Designations: $\mathrm{R}$ - regimes, 0 - without air flow, 1 - with outside air flow, $\mathrm{N}$ - produced heat power, $\mathrm{Q}$ - consumption of heat energy, COP - compressor's coefficient of performance, $\mathrm{K}$ - common energy transfer coefficient.

In Table 3 experimental results when outside air temperature was under $+6^{\circ} \mathrm{C}$, and the evaporator was heated by outside or inside air flow using a ventilator (November, 2010), are presented.

On November 4 afternoons at the outside air temperature $+9^{\circ} \mathrm{C}$ the heat power reached 14.3 $\mathrm{kW}$. During the night temperature decreased and in the morning November 4 it was only $+3^{\circ} \mathrm{C}$. The evaporators were slightly cowered with hoarfrost and the heat power has diminished to $9.9 \mathrm{~kW}$. At switching on the ventilator with outside air flow after 5 minutes the heat power increase by $1,2 \mathrm{~kW}$ and later reached $13.7 \mathrm{~kW}$, although hoarfrost of the evaporator's plates did not thaw. When warm air $\left(+10^{\circ} \mathrm{C}\right)$ from the ante-room was blown to the evaporator, fast hoarfrost thaw started and the heat power increased up to $15.7 \mathrm{~kW}$. At switching the ventilator off and on repeatedly, the heat power changed correspondingly. Similar investigations several times during a week have been carried out. Always it resulted in the increase of produced heat power and the COP of the heat pump. 
Evaporator's heating by outside or inside air flow in November, 2010

Table 3.

\begin{tabular}{|c|c|c|c|c|c|c|c|c|}
\hline \multirow{2}{*}{ Date } & \multirow{2}{*}{$\mathbf{R}$} & \multirow{2}{*}{$\begin{array}{c}\text { Time, } \\
\text { h }\end{array}$} & \multirow{2}{*}{$\mathbf{T}_{\text {out }},{ }^{\circ} \mathrm{C}$} & \multirow{2}{*}{$\begin{array}{c}\mathbf{Q}, \\
\mathrm{kWh} / \mathbf{h}\end{array}$} & \multicolumn{2}{|c|}{$\mathbf{N}, \mathbf{k W}$} & \multirow{2}{*}{ COP } & \multirow{2}{*}{$\mathbf{K}$} \\
\hline & & & & & from - up to & difference & & \\
\hline $4-5$ & 0 & 17 & 6 & 11.53 & $14.8-9.9$ & -4.9 & 2.54 & 2.54 \\
\hline \multirow{4}{*}{5} & 1 & 2.9 & 5 & 12.76 & 13.7 & +3.8 & 2.67 & 2.42 \\
\hline & 3 & 0.6 & 10 & \multirow{3}{*}{12.50} & 15.7 & +5.8 & \multirow{3}{*}{2.73} & \multirow{3}{*}{2.73} \\
\hline & 0 & 2.9 & 7 & & 13.4 & -2.3 & & \\
\hline & 3 & 0.5 & 10 & & 14.5 & +4.6 & & \\
\hline $5-6$ & 2 & 21.8 & 6 & $\overline{11.19}$ & 14.6 & & 3.13 & 2.74 \\
\hline $6-8$ & 1 & 48.5 & 2 & 12.10 & & & 2.67 & 2.39 \\
\hline 8 & 0 & 1.75 & 3 & 10.86 & 10.7 & & 2.52 & 2.28 \\
\hline $8-10$ & 2 & 41.3 & 8 & 11.42 & 15.6 & +4.9 & 2.85 & 2.54 \\
\hline 10 & 0 & 0.4 & 4 & & 10.8 & -4.8 & & \\
\hline $10-12$ & 1 & 46.9 & 5 & 10.68 & 13.6 & +2.8 & 3.15 & 2.75 \\
\hline 12 & 3 & 0.25 & 9 & & & & & \\
\hline $12-15$ & 0 & 72 & 8 & 10.07 & & & 2.98 & 2.98 \\
\hline
\end{tabular}

Designations: $\mathrm{R}$ - regimes, 0 - without air flow, 1 - with outside air flow, 2 - with outside and inside air flow, 3 - with inside air flow only, $\mathrm{T}_{\text {out }}$ - average outside air temperature, $\mathrm{N}$ - produced heat power, $\mathrm{Q}$ - consumption of heat energy, $\mathrm{COP}$ - compressor's coefficient of performance, $\mathrm{K}$ - common energy transfer coefficient.

Experimental results, when the outside air flow was directed to the evaporator covered by screens, in Table 4 are presented. One of experiments on October 6 when outside temperature reached $+7^{\circ} \mathrm{C}$ has been carried out. In the morning both evaporators were covered by hoarfrost. In the afternoon at 13.10 p.m. the ventilator was switched on. In 10 minutes the heat power of the non-covered evaporator increased from $11.3 \mathrm{~kW}$ to $14.2 \mathrm{~kW}$. After switching off the ventilator in 25 minutes the heat power diminished to $11.3 \mathrm{~kW}$ and the evaporator's plates did not thaw. After that a row of experiments have been carried out using the screens around the evaporator from outside and inside. Warm air flow $\left(+12^{\circ} \mathrm{C}\right)$ from the ante-room was delivered to the evaporator. Fast heat power increase started, reaching its maximum at $15.4 \mathrm{~kW}$. The COP of the heat pump increased accordingly from 2.5 to 3.4 . When the screens were taken off the indexes decreased (Table 4).

Table 4.

Experimental results when the evaporator covered by screens (2010)

\begin{tabular}{|c|c|c|c|c|c|c|c|}
\hline Date & $\mathrm{R}$ & Time, $\mathrm{h}$ & $\begin{array}{c}\mathrm{T}_{\text {out }}, \\
{ }^{\circ} \mathrm{C}\end{array}$ & $\begin{array}{c}\mathrm{Q}, \\
\mathrm{kWh} / \mathrm{h}\end{array}$ & $\begin{array}{c}\text { Heat power, } \\
\mathrm{kW}\end{array}$ & $\mathrm{COP}$ & Common K \\
\hline \multirow{2}{*}{ Nov. 6 } & 0 & 2.9 & 5 & 11.25 & 11.3 & 2.49 & 2.49 \\
\cline { 2 - 8 } & 1 & 1.7 & $12^{*}$ & 13.33 & $11.3-15.4$ & 3.14 & 2.82 \\
\hline \multirow{2}{*}{ Nov. 8} & 0 & 5.5 & 4 & 10.90 & 10.6 & 2.29 & $2.07^{* *}$ \\
\cline { 2 - 8 } & 1 & 1,7 & $10^{*}$ & 13.25 & $10.6-14.3$ & 3.1 & 2.78 \\
\hline
\end{tabular}

Designations: $\mathrm{R}$ - regimes, 0 - without air flow, 1 - with inside air flow, $\mathrm{T}_{\text {out }}$ - average outside air temperature, Q - consumption of heat energy, COP - compressor's coefficient of performance, K common energy transfer coefficient, * - air temperature in ante-room, $* *$ - for short time the electric heater is switched on. 
The process of the investigation in Fig. 2 is shown. Steep increase in the heat power just after switching on the ventilator in Fig.3 is seen. Similar results in repeated experiments are obtained. The evaporator block with opened screens after thawing in Fig.4 is given. On the left side (Fig.4) another evaporator's block is seen, which at the same time did not thaw.

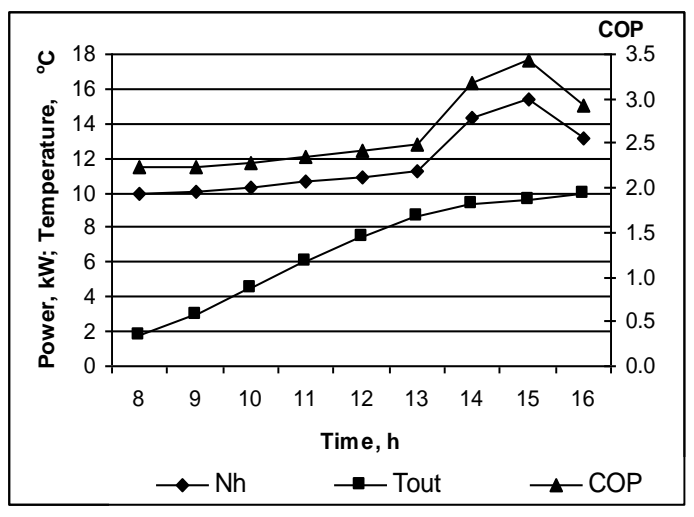

Fig.2. The gain of the COP and heat energy power $\mathrm{N}_{h}$ of the heat pump: $\mathbf{T}_{\text {out }}-$ outside air temperature

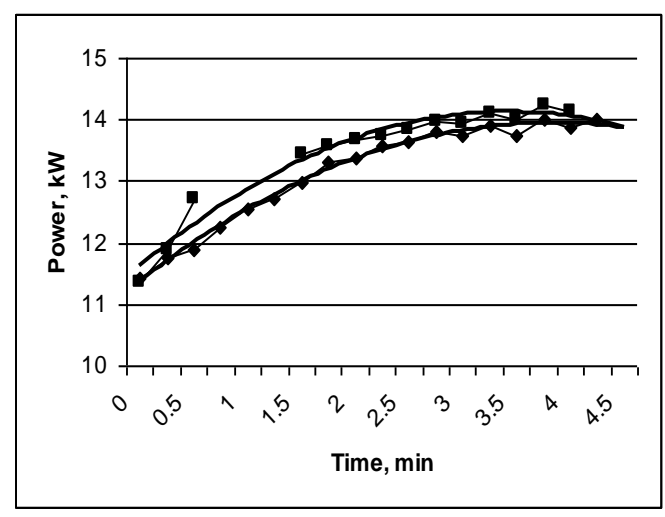

Fig.3. The dynamics of the gain in power during 4 minutes after the start of warm air flow: upper curve - with screen, lower without screen

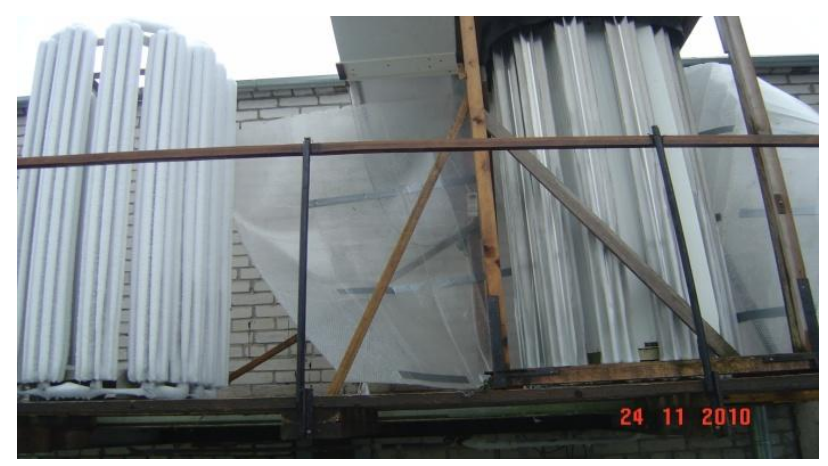

Fig.4. The evaporator block with opened screens after thawing

\section{Conclusions}

From our two years investigation results about the possibility of the use of an outside air heat pump for piglets resting place floor panels heating, the following is concluded:

1. In summer period at the outside air temperature above $10-12^{\circ} \mathrm{C}$ the coefficient of performance of a heat pump is above 3 and the heat consumption $5-9 \mathrm{kWh} / \mathrm{h}$. The evaporators of the heat pump are not covered by hoarfrost.

2. At outside air temperature $3-10^{\circ} \mathrm{C}$ the heat demand increases. The heat pump operates constantly or with small breaks. The evaporators start to be covered by hoarfrost. The exploitation indexes of the heat pump decreases. The heat transfer coefficient becomes fewer than 2.5.

3. At the positive outside air temperature within the limits of $2-5^{\circ} \mathrm{C}$ the evaporators coverage by hoarfrost increases, and without additional undertakings to this, the heat pump operation is not useful.

4. The thawing of the hoarfrost using additional air flow in successful only in the outside temperature interval $6-12^{\circ} \mathrm{C}$. 
5. At the outside air temperature under $12^{\circ} \mathrm{C}$ it is recommended to blow the heat pump evaporators by warmed air flow. In our experimental examination the obtained gain of the heat power was by $3.7-4.1 \mathrm{~kW}$, and the COP of the heat pump increased by $0.6-0.7 \mathrm{on}$ the average.

6. The investigation has shown that the blowing of the evaporators by warmed air can prolong the operation of the heat pump at lower outside temperature period. In our experimental pigsty using the transformed by a heat pump the heat energy for piglets resting place floor heating from May till the middle of November (2010) the economy was about $1180 €$.

7. Our experimental investigation has shown that using the worm air from a pigsty ventilation system for evaporators warming, the heat pump operation is possible even at negative outside temperature.

\section{Acknowledgment}

Research is completed by financial support of European Structural Fund: Attraction of human resources for investigation of renewable energy resources. Realized by the Project Department of the Latvia University of Agriculture (contract no. 2009/0225/1DP/1.1.1.2.0/09/APIA/VIAA/129).

\section{References}

1. Blumberga D. Heat pump. R.: RTU. 2008. 140 p. (in Latvian).

2. Reay D., Macmichael D. Heat Pumps. M.: Energoizdat. 1982. 220 p. (in Russian).

3. http://www.meteo.lv (in Latvian).

4. Ilsters A., Ziemelis I., Zagorska V. Warming of Piglets Resting Places by Air Heat Pump in Dependence on Outside Air Temperature. Proceedings of the $9^{\text {th }}$ International Scientific Conference "Engineering for Rural Development", Jelgava, Latvia, 2010, pp. 106 - 111. 